\title{
Pemahaman Sumber Daya Manusia, Implementasi Standar Akuntansi Pemerintah dan Kualitas Informasi Keuangan pada Satuan Kerja Kementerian Sosial
}

Putri Zaenab Syafitri Siregar ${ }^{1}$, Adi Wiratno ${ }^{2}$

${ }^{1}$ Universitas Pancasila, Jl. Srengseng Sawah, Jagakarsa, Jakarta Selatan, 12640

${ }^{2}$ Universitas Jenderal Soedirman, Jl. HR. Boenyamin 708, Grendeng, Purwokerto Utara, Jawa Tengah 53122

\section{INFO ARTIKEL}

JEL Classsification:

M41

M42

Keywords:

accounting standards, quality of financial information, competencies.

\section{ABSTRACT}

Government agencies today must follow accounting developments to create accountability and transparency. This study aims to obtain evidence of the influence of understanding of human resources and the implementation of government accounting standards on the quality of financial information. This research uses survey method. Sampling method used by writer is simple random sampling. Respondents are all planners, financial managers, financial statements compilers within the Ministry of Social RI as many as 779 people, with a sample of 88 people. Hypothesis test using multiple linear regression. The results showed that the understanding of Human Resources and Implementation of Government Accounting Standards have a significant positive impact on the Quality of Financial Information. It also shows that there is a synergy between the understanding of human resources and the implementation of government accounting standards in achieving the quality of financial information within the Ministry of Social RI in line with expectations.

\begin{abstract}
ABSTRAK
Lembaga pemerintah saat ini, harus mengikuti perkembangan akuntansi agar tercipta akuntabilitas dan transparansi. Salah satu upayanya yaitu penyampaian laporan pertanggungjawaban keuangan pemerintah yang berkualitas. Penelitian ini bertujuan untuk memperoleh bukti tentang pengaruh pemahaman sumber daya manusia dan implementasi standar akuntansi pemerintah terhadap kualitas informasi keuangan. Penelitian ini menggunakan metode survey. Metode pengambilan sampel yang digunakan penulis adalah simple random sampling. Responden adalah seluruh perencana, pengelola keuangan, penyusun laporan keuangan dilingkungan Kementerian Sosial RI sebanyak 779 orang, dengan jumlah sampel sebanyak 88 orang. Uji hipotesis menggunakan regresi linier berganda. Hasil penelitian menunjukkan Pemahaman Sumber Daya Manusia dan Implementasi Standar Akuntansi Pemerintah berpengaruh signifikan positif terhadap Kualitas Informasi Keuangan. Hal ini juga menunjukkan bahwa terdapat sinergi antara pemahaman sumber daya manusia dan implementasi standar akuntansi pemerintah dalam mencapai kualitas informasi keuangan dilingkungan Kementerian Sosial RI yang sesuai dengan harapan.
\end{abstract}

*Email Korespondensi: 'celumoet@ymail.com, 2adiwiratno08@yahoo.com 


\section{Pendahuluan}

Reformasi dibidang keuangan yang dilakukan pemerintah, ditandai dengan berlakunya Undang-Undang Nomor 18 Tahun 2016 tentang Anggaran Pendapatan dan Belanja Negara dan Undang-Undang Nomor 1 Tahun 2004 tentang Perbendaharaa Negara, yang mengamatkan Menteri/Pimpinan Lembaga sebagai Pengguna Anggaran/Barang mempunyai tugas antara lain menyusun dan menyampaikan laporan keuangan Kementerian/Lembaga yang dipimpinnya. Anggaran Pendapatan Belanja Negara (APBN) yang semakin besar merupakan salah satu faktor pentingnya akuntansi pemerintahan. Perkembangan berikutnya semakin besar dana yang dikelola menyebabkan adanya tuntutan transparansi sebagai hasil reformasi, maka pemerintah harus mampu menyediakan pertanggungjawaban keuangan Negara yang semakin memadai. Pemberian opini Tidak Memberikan Pendapat (TMP) atas laporan keuangan Negara seharusnya tidak terjadi.

Dalam rangka memenuhi kualitas laporan keuangan, pemerintah pusat mengembangkan sebuah Sistem Akuntansi Pemerintah Pusat
(SAPP). Sistem Akuntansi Pemerintah Pusat (SAPP) akan menghasilkan Laporan Keuangan Pemerintah Pusat (LKPP) yang akan diperiksa terlebih dahulu oleh Badan Pemeriksaan Keuangan (BPK) sebelum diserahkan ke DPR. Berdasarkan audit BPK atas LKPP tahun 2015 yang hasilnya digunakan sebagai dasar penyusunan Laporan Hasil Pemeriksaan (LHP) atas LKPP tahun 2015.

Hasil pemeriksaan atas 86 LKPP , menunjukan terdapat 56Laporan Keuangan Kementerian Lembaga (LKKL) yang mendapat opini WajarTanpaPengecualian(WTP), 26LKKL mendapatkan opini Wajar Dengan Pengecualian (WDP), serta 4 LKKL mendapatkan opini Tidak Memberikan Pendapat (TMP) dan salah satunya adalah Kementerian Sosial RI. Pengamatan pada Kementerian Sosial RI pada tahun 2015 laporan keuangan Kementerian Sosial RI mendapatkan opini TMP dari BPK, sedangkan pada tahun 2014 Kementerian telah mendapatkan opini Wajar Dengan Pengecualian. Berdasarkan temuan BPK tersebut, menunjukan bahwa kualitas informasi laporan keuangan Kementerian Sosial RI tidak dapat dipertanggungjawabkan kebenarannya dan masih kurang bagus.

Tabel 1. Perkembangan Capaian Kualitas

Laporan Keuangan Kementerian Sosial RI tahun 2011-2015

\begin{tabular}{llllll}
\hline Uraian & $\begin{array}{l}\text { Tahun } \\
\mathbf{2 0 1 1}\end{array}$ & $\begin{array}{l}\text { Tahun } \\
\mathbf{2 0 1 2}\end{array}$ & $\begin{array}{l}\text { Tahun } \\
\mathbf{2 0 1 3}\end{array}$ & $\begin{array}{l}\text { Tahun } \\
\mathbf{2 0 1 4}\end{array}$ & $\begin{array}{l}\text { Tahun } \\
\mathbf{2 0 1 5}\end{array}$ \\
\hline Jumlah Satker & 284 & 287 & 284 & 287 & 287 \\
Pagu Anggaran & $56,45 \mathrm{~T}$ & $62,37 \mathrm{~T}$ & $57,53 \mathrm{~T}$ & $64,23 \mathrm{~T}$ & $67,28 \mathrm{~T}$ \\
Opini BPK & WTP-DPP & WTP-DPP & WTP-DPP & WDP & TMP \\
\hline
\end{tabular}

Sumber: Biro Keuangan Kementerian Sosial RI

Pemberian opini tersebut berdasarkan hasil penilaian BPK RI atas Kualitas Laporan Keuangan Kementerian Sosial RI yang masih terdapat bebberapa kelemahan atau kekurangan pada Tahun 2011 Kementerian Sosial mendapat opini Wajar Tanpa Pengecualian Dengan Paragraf Penjelasan (WTP-DPP) dikarenakan laporan keuangan yang telah disusun sudah sesuai dengan prinsip akuntansi dengan baik dan semua bukti-bukti diakui kewajarannya walaupun masih terdapat kesalahan yang tidak dianggap material dan tidak berpengaruh signifikan dalam pengelolaan Penerimaan Negara Bukan Pajak (PNBP) karena diluar mekanisme APBN. Tahun 2012, Kementerian Sosial mendapatkan opini Wajar Tanpa Pengecualian Dengan Paragraf 
Penjelasan (WTP-DPP) sama seperti tahun sebelumnya dan permasalahan yang sama masih ditemukan ditahun ini karena belum tuntas ditindaklanjutin. Sedangkan pada Tahun 2013, Kementerian Sosial masih mendapat opini yang sama seperti tahun sebelumnya Wajar Tanpa Pengecualian Dengan Paragraf Penjelasan (WTP-DPP) dan masih terdapat masalah yang dianggap tidal material dan tidak berpengaruh signifikan. Hal ini terjadi dalam pengelolaan Barang Milik Negara yang belum tepat.

PadaTahun 2014, Kementerian Sosial mendapat opini Wajar Dengan Pengecualian (WDP) dibandingkan tahun sebelumnya mengalami penurunan opini, ini dikarenakan masih terdapat kekurangan pada perbedaan antara saldo yang tercatat pada Sisten Akuntansi Keuangan (SAK) dan SIMAKBMN (penerbitan Barang Milik Negara belum sepenuhnya terlaksana), serta masih adanya akun neraca yang tidak diyakini kewajarannya dalam pengelolaan persediaan belum memadai dan tidak sesuai aturan yang berlaku. Dan Tahun 2015, Kementerian Sosial mendapat opini Tidak Memberikan Pendapat (TMP) dibandingkan tahun sebelum pemberian opini semakin menurun, ini disebabkan adanya perbedaan signifikan antara saldo yang terdapat pada Sistem Akuntansi Keuangan (SAK) dan Sistem Akuntansi Barang Milik Negara (SIMAKBMN), hampir seluruh akun neraca tidak dapat diyakini kewajarannya khususnya pada akun bantuan sosial, Catatan atas Laporan Keuangan (CaLK) belum mengungkapkan informasi penting yang terkait dengan laporan keuangan serta kurangnya pengetahuan SDM tentang perubahan dari basis kas menjadi basis kas menuju akrual.

Penelitian sebelumnya yang tidak berpengaruh dengan penelitian sekarang adalah Penelitian yang dilakukan oleh Winidyaningrum (2010) dengan judul Pengaruh Sumber Daya Manusia dan Pemanfaatan Teknologi Informasi terhadap Keterandalan dan Ketepatan Waktuan Pelaporan Keuangan
Pemerintah Daerah dengan Variabel Intervening Pengendalian Intern Akuntansi (Studi Empiris diPemda Subosukawono Sraten). Penelitian ini menunjukkan bahwa Sumber Daya Manusia dan Pemanfaatan Teknologi Informasi berpengaruh terhadap Keterandalan Pelaporan Keuangan Pemda melalui Pengendalian Internal Akuntansi sedangkan Pemanfaatan Teknologi Informasi berpengaruh terhadap ketepatwaktuan pelaporan keuangan pemda dan Sumber Daya Manusia tidak berpengaruh terhadap Ketepatwaktuan pelaporan keuangan pemerintah daerah. Dan Penelitian yang dilakukan oleh Putra dan Amar (2013) dengan judul Pengaruh Kompetensi Sumber Daya Manusia, Penerapan Sistem Pengendalian Intern Pemerintah, dan Penerapan Standar Akuntansi Pemerintah terhadap Kualitas Penyajian Laporan Keuangan menunjukan bahwa Kompetensi Sumber Daya Manusia dan Penerapan Sistem Pengendalian Intern Pemerintah berpengaruh positif terhadap Kualitas Laporan Keuangan tetapi Penerapan Standar Akuntansi Pemerintah tidak berpengaruh terhadap Kualitas Penyajian Laporan Keuangan.

Sedangkan penelitian yang terdahulu yang berpengaruh adalah Yudianta dan Erawati (2009) dengan judul Pengaruh Sumber Daya Manusia, Teknologi Informasi dan Pengendalian Intern terhadap Kualitas Laporan Keuangan menunjukan bahwa Vaiabel Sumber Daya Manusia tidak berpengaruh terhadap Kualitas Laporan Keuangan tetapi Teknologi Informasi dan Pengendalian Inern berpengaruh positif terhadap Kualitas Laporan Keuangan. Dan Irvan Permana (2011) mengenai Pengaruh Penerapan Standar Akuntansi Pemerintah terhadap Kualitas Laporan Keuangan Pemerintah Daerah dan Implikasinya pada Akuntabilitas pada Dinas Kota Bandung menunjukkan bahwa Penerapan StandarAkuntansi Pemerintah berpengaruh signifikan terhadap Kualitas laporan Keuangan Pada Dinas Kota Bandung dan Standar Akuntansi Pemerintah dan Kualitas Laporan Keuangan tidak berpengaruh terhadap Akuntabilitas pada Dinas Kota bandung. 
Penelitian yang dilakukan oleh Kiranayanti dan Erawati (2016) dengan judul Pengaruh Sumber Daya Manusia, Sistem Pengendalian Intern, Pemahaman Basis Akrual Terhadap Kualitas Laporan Keuangan Daerah, hanya meneliti pengaruh Sumber Daya Manusia, Sistem Pengendalian Intern, dan Pemahaman Basis Akrual terhadap Kualitas Laporan Keuangan Daerah. Sedangkan pada penelitian ini menambah variabel Implementasi Standar Akuntansi Pemerintah. Penelitian oleh Irvan Permana (2011) dengan judul Pengaruh Penerapan Standar Akuntansi Pemerintah Terhadap Kualitas Laporan Keuangan Pemerintah Daerah dan Implikasinya pada Akuntabilitas, hanya meneliti dengan satu variabel pada penelitian ini. Objek penelitian yang dilakukan oleh Kiranayanti dan Erawati (2016), Maksyur (2015), Sukmaningrum (2012), Putra dan Amar (2013), Permana (2011), Irwana (2010), Winidyaningrum (2010), Zainul Rachman Lili (2009) Pemerintahan Daerah, sedangkan penelitian ini dilakukan pada seluruh satuan kerja dilingkungan Kementerian Sosial RI.

Penelitian yang dilakukan oleh terdahulu hanya melihat data pada periode setahun sedangkan pada penelitian ini melihat tahuntahun sebelumnya. Tujuan penelitian ini secara spesifik adalah untuk mengetahui pengaruh variabel Sumber Daya Manusia (X1) dan Standar Akuntansi Pemerintah (X2) terhadap Kualitas Informasi Keuangan, Yaitu Untuk menganalisis dan menginpestigasi pengaruh Pemahaman Sumber Daya Manusia terhadap Kualitas Informasi Keuangan. Untuk menganalisis dan menginpestigasi pengaruh Implementasi Standar Akuntansi Pemerintah terhadap Kualitas Informasi Keuangan.

\section{Telaah teori dan pengembangan hipotesis}

Pengaruh Pemahaman Sumber Daya Manusia terhadap Kualitas Informasi Keuangan

Setiap bagian dalam sebuah organisasi, tentu dibuat untuk mempermudah pembagian kerja, sehingga organisasi tersebut bisa berjalan efektif dan efisien. Pembagian tersebut tentu didasarkan pada berbagai pertimbangan yang dianggap akan mempermudah pekerjaan tersebut. Salah satunya adalah pertimbangan SDM (Sumber Daya Manusia) yang akan menduduki bagian tersebut. SDM yang ditempatkan harus memiliki kemampuan yang sesuai dengan tugas pokok dan fungsi yang telah ditetapkan diawal.

Dengan adanya prinsip orang yang tepat ditempat yang tepat (the right man in the right place) akan memberikan jaminan terhadap kestabilan, kelancaran dan efisiensi kerja", sehingga tujuan organisasi dapat dicapai dengan baik. Hal ini juga berlaku untuk bagian keuangan pada setiap kementerian/lembaga, tujuan bagian ini adalah untuk dapat menghasilkan laporan keuangan yang merupakan salah satu media penyampaian informasi, dengan kualitas yang baik agar dapat bermanfaat bagi para penggunanya. Dengan demikian bagian tersebut harus diisi orang yang tepat, yaitu SDM yang memiliki kompetensi dalam bidang keuangan, sehingga dapat tercapainya tujuan yaitu laporan keuangan yang berkualitas baik, yang dapat bermanfaat bagi para penggunanya.

Penelitian yang pernah membukti bahwa pemahaman sumberdaya manusia mempengaruhi kualitas informasi keuangan antara lain Kiranayanti dan Erawati (2016), Maksyur (2015), Winidyaningrum (2010), Lestari (2013), Yudianta dan Erawati (2009), Berdasarkan pada uraian mengenai pengaruh pemahaman sumber daya manusia terhadap kualitas penyajian informasi keuangan, maka dapat dirumuskan hipotesis sebagai berikut:

H1: Pemahaman Sumber Daya Manusia berpengaruh positif dan signifikan terhadap Kualitas Informasi Keuangan. 
Pengaruh Implementasi Standar Akuntansi Pemerintah terhadap Kualitas Informasi Keuangan

Tujuan penerapan Standar Akuntansi Pemerintah adalah dalam rangka penyusunan dan penyajian laporan keuangan yang berkualitas. Pemerintah Indonesia menetapkan standar akuntansi yang disebut dengan Standar Akuntansi Pemerintah (SAP) yang dituangkan dalam Peraturan Pemerintah Nomor 71 tahub 2010 sebagai pedoman dalam menyusun dan menyajikan laporan keuangan untuk dapat meningkatkan kualitas laporan keuangan bagi pemerintah.

Penetapan Standar Akuntansi Pemrintah merupakan bentuk keseriusan pemerintah dalam rangka meningkatkan transparansi dan akuntabilitas dalam pengelolaan keuangan melalui penyajian informasi keuangan yang berkualitas. Dengan demikian secara teoritis penerapan standar akuntansi pemerntah dapat mencapai tujuan atau hasil yan ingin dicapai, yaitu dapat mewujudkan dan meningkatkan kualitas dari laporan keuangan dengan menerapkan pernyataan yang terkandung dalam Standar Akuntansi Pmerintahan. Penelitian yang pernah membukti bahwa penerapan standar akuntansi pemerintah terhadap kualitas informasi keuangan antara lain Suwita (2015); Nugraheni dan Subaweh(2011). Berdasarkan hal tersebut, maka dirumuskan hipotesis sebagai berikut:

H2: Implementasi StandarAkuntansi Pemerintah berpengaruh positif dan signifikan terhadap Kualitas Informasi Keuangan.

\section{Metode Penelitian}

Desain Penelitian yang digunakan dalam penelitian ini adalah deskriptif kausalitas karena penelitian ini berusaha menjelaskan bagaimana hubungan dan pengaruh suatu variabel terhadap variabel lainnya dengan menggunakan pendekatan studi kasus. Sehubungan dengan jenis penelitian ini, maka metode penelitian yang digunakan adalah metode survey. Adapun ciri dari metode survey adalah tujuanya dapat bersifat deskriptif dab juga verifikasi, data dikumpulkan dari sampel yang telah ditentukan, data variabel penelitian dijaring dengan menggunakan alat pengumpulan data tertentu yaitu kuesioner (Singarimbun, 2004). Tempat dan Waktu Penelitian ini akan dilakukan pada seluruh Satuan Kerja Kementerian Sosial RI. Waktu pelaksanaan penelitian dilakukan selama 5 tahun dari tahun 2011 sampai dengan tahun 2015. Jenis dan Sumber Data yang digunakan adalah Data Primer Jenis data yang diperoleh langsung dari responden dalam bentuk penyebaran angket/kuesioner.

Populasi dan Sampel dalam penelitian ini terdiri dari para perencana keuangan, pengelola keuangan, dan penyusun laporan keuangan yang bekerja pada seluruh satuan kerja Kementerian Sosial RI . Sampel penelitian adalah sebagian dari populasi yang diambil sebagai sumber data dan dapat mewakili seluruh populasi. Teknik sampling yang digunakan dalam penelitian ini adalah teknik Purposive Random Sampling, yaitu sampling yang digunakan jika peneliti mempunyai pertimbangan tertentu dalam pengambilan sampelnya atau penentuan sampel untuk tujuan tertentu. Kriteria pengambilan sampel penelitian ini adalah Perencana, Pengelola Keuangan dan Penyusun Laporan Keuangan yaitu tim perencana, bendahara, bendahara pengeluaran pembantu, petugas Sistem Akuntansi Keuangan (SAK) dan Sistem Informasi Manajemen Akuntansi Keuangan Barang Milik Negara (SIMAK-BMN) pada setiap Satuan Kerja Kementerian Sosial RI baik dipusat maupun didaerah. 
Tabel 2. Populasi dan Sampel

\begin{tabular}{llll}
\hline No & Keterangan & Populasi & Sampel \\
\hline 1. & Tenaga Perencana & 203 & 23 \\
2. & Pengelola Keuangan & 291 & 33 \\
3. & Penyusun Laporan Keuangan & 285 & 32 \\
& Jumlah & 779 & 88 \\
\hline
\end{tabular}

Sumber: Biro Keuangan Kementerian Sosial RI

Teknik pengumpulan data dalam penelitian ini terjadi dari kuesioner, yaitu sejumlah pertanyaan tertulis yang digunakan untuk memperoleh informasi dari responden dalam arti laporan tentang pribadinya, atau hal-hal yang diketahui (Arikunto, 2005). Kuesioner untuk penelitian ini menggunakan kuesioner tertutup, yakni sudah disediakan jawabannya sehingga responden tinggal memilih jawabannya. Kepustakaan, yaitu berupa dokumen, laporan, Undang-undang, buku, jurnal yang berhubungan dengan penelitian. Instrumen penelitian yaitu alat pengambilan data yang digunakan dalam penelitian ini adalah data primer ( data langsung/ original) yang diperoleh secara langsung dari para responden, yaitu para pengelola keuangan, dan penyusun laporan keuangan di Kementerian Sosial RI dengan cara membagikan kuesioner dan para responden akan menjawab pertanyaan yang ada dalam kuesioner (Ridwan, 2006).

Kuesioner diantar langsung kepada responden dan diberikan tenggang waktu 10 hari untuk mengisi kuesioner tersebut. Kuesioner yang telah diisi diambil sendiri oleh penulis untuk menghindari hal-hal yang tidak diinginkan, seperti hilang atau tidak kembalinya kuesioner tersebut. Setelah itu barulah hasil kuesioner yang telah terkumpul tersebut nantinya diklasifikasikan menurut pembagian populasinya, didata ulang hasil jawaban dari tiap-tiap pertanyaan tersebut diolah dengan menggunakan instrumen penelitian yang sudah ditetapkan sesuai dengan jenis penelitiannya dan kemudian dirangkumkan.

Skala pengukuran meruakan kesepakata yang digunakan sebagai acuan untuk menentukan panjang pendenya interval yang ada dalam alat ukur, sehingga alat ukur tersebut bila digunakan dalam pengukuran akan menghasilkan data kuantitatif (Sugiyono, 2008). Skala pengukuran yang digunakan dalam penelitian ini adalah skala Likert. Skala Likert digunakan untuk mengukur sikap, pendapat dan persepsi seseorang atau kelompok orang tentang fenomena sosial. Dengan skala likert, maka variabel yang akan diukur dijabarkan menjadi indikator variabel. Kemudian indikator tersebut dijadikan sebagian titik tolak untuk menyusun item-item instrumen yang dapat berupa pertanyaan atau pernyataan (Sugiyono,2008). Skala interval yang digunakan mengambil bentuk dari skala likert, menggunakan 5 angka penilaian 1 samapai dengan 5. Dimana 1 bernilai sangat tidak setuju dan 5 sangat setuju.

Teknik analisis data dilakukan dengan uji regresi berganda. Pengujian regresi berganda dilakukan setelah uji asumsi klasik yang terdiri terdiri dari uji normalitas, uji multikolinearitas dan uji heteroskedastitas. Uji normalitas dilakukan dengan uji kolmogorov - smirnov. Uji multikolinearitas dilakukan dengan melihat angka VIP (variance Inflation Factor). Uji Heteroskedastisitas menggunakan uji scatterplot. Analisis deskriptif digunakan untuk mendeskriftifkan variabel. Uji koefisien determinasi (Adjusted R Square) digunakan untuk mengukur seberapa baik garis regresi sesuai dengan data aktualnya (goodness of fit). Koefisien determinasi ini mengukur presentase total variasi variabel dependen $Y$ yang dijelaskan oleh variabel independen didalam garis regresi. Pengujian hipotesis 1 dan 2 dilakukan dengan 
melihat hasil uji t. Jika hasil uji t menunjukkan nilai signifikasi $<0,05$ (pada $\alpha=0.05$ ) maka hipotesis penelitian terbukti (H0 ditolak dan H1 diterima).

\section{Hasil Penelitian dan Pembahasan}

Penelitian ini bertujuan untuk menganalisis pengaruh pemahaman sumber daya manusia dan implementasi standar akuntansi pemerintah terhadap kualitas informasi keuangan. Sampel dianalisis sejumlah 88 sampel. Hasil uji asumsi klasik menunjukkan distribusi nilai residual variabel adalah normal $(0,457>0,05)$. Hasil uji multikolinearitas menunjukkan semua nilai variabel memiliki nilai variance inflation faktor $<10$. Hasil uji scatterplot menunjukkan bahwa gambar tersebar dan tidak berpola sehingga dapat disimpulkan bahwa tidak terjadi heteroskedastisitas. Uji validitas menunjukan hasil bahwa semua indikator pada semua variabel terbukti valid dan reliabel, karena nilai korelasinya signifikan dan nilai cronbach alpha $>0,6$. Deskripsi variabel digambarkan sebagaimana tabel berikut :

Tabel 3. Deskripsi Variabel

\begin{tabular}{llcccc}
\hline No & Variabel & $\begin{array}{l}\text { Nilai } \\
\text { Rata-Rata }\end{array}$ & $\begin{array}{c}\text { Standar } \\
\text { Deviasi }\end{array}$ & Minimum & Maksimum \\
\hline 1 & $\begin{array}{l}\text { Pemahaman Sumber Daya } \\
\text { Manusia (X1) }\end{array}$ & 88 & 4,463 & 48,00 & 67,00 \\
2 & $\begin{array}{l}\text { Implementasi Standar Akuntansi } \\
\text { Pemerintahan (X2) }\end{array}$ & 88 & 5,477 & 65,00 & 89,00 \\
3 & Kualitas Informasi Keuangan (Y) & 88 & 3,44 & 36,00 & 50,00 \\
\hline
\end{tabular}

Hasil pengujian model penelitian dan hipotesis terangkum pada tabel berikut :

Tabel 4. Rangkuman Hasil Pengujian

\begin{tabular}{lrrrr}
\hline Keterangan & \multicolumn{1}{l}{ B } & Std. Error & t-hitung & Sig. \\
\hline Pemahaman Sumber Daya Manusia (X1) & 0,259 & 0,088 & 2,950 & 0,004 \\
Implementasi Standar Akuntansi Pemerintahan & 0,299 & 0,071 & 4,187 & 0,000 \\
(X2) & & & & \\
Constant & 3,400 & & & \\
R-Square & 0,592 & & & \\
Adjusted R-Square & 0,583 & & & \\
F-hitung & 61,774 & & & \\
Sig. F & 0.000 & & & \\
\hline
\end{tabular}

Persamaan regresi hasil pengujian adalah sebagai berikut :

$$
\mathrm{Y}=3,40+0,259 \mathrm{X}_{1}+0,299 \mathrm{X}_{2}+\mathrm{e}
$$

Koefiensi regresi variabel Pemahaman Sumber Daya Manusia $\left(\mathrm{X}_{1}\right)$ adalah sebesar 0.259 , artinya jika variabel independen lain nilainya tetap dan nilai dari pemahaman sumber daya manusia mengalami kenaikan 1 poin, maka nilai dari kualitas informasi keuangan akan mengalami kenaikan sebesar 0.259 poin. Begitupula sebaliknya, jika variabel independen lain nilainya tetap dan nilai dari pemahaman sumber daya manusia mengalami penurunan 1 poin, maka nilai dari variabel kualitas informasi keuangan akan mengalami penurunan sebesar 
0.259 poin. Dalam hal ini pengaruh dari variabel independen pemahaman sumber daya manusia adalah berbanding lurus dengan kualitas informasi keuangan, artinya semakin meningkat pemahaman sumber daya manusia, maka nilai kualitas informasi keuangan juga akan semakin meningkat, begitu pula sebaliknya.

Koefiensi regresi variabel implementasi standar akuntansi pemerintahan $\left(\mathrm{x}_{2}\right)$ adalah sebesar 0.299, artinya jika variabel independen lain nilainya tetap dan nilai dari implementasi standar akuntansi pemerintahan mengalami kenaikan 1 poin, maka nilai dari kualitas informasi keuangan akan mengalami kenaikan sebesar 0.299 poin. Begitupula sebaliknya, jika variabel independen lain nilainya tetap dan nilai dari implementasi standar akuntansi pemerintahan mengalami penurunan 1 poin, maka nilai dari variabel kualitas informasi keuangan akan mengalami penurunan sebesar 0.299 poin. Dalam hal ini pengaruh dari variabel independen implementasi standar akuntansi pemerintahan adalah berbanding lurus dengan kualitas informasi keuangan, artinya semakin meningkat implementasi standar akuntansi pemerintahan, maka nilai kualitas informasi keuangan juga akan semakin meningkat, begitu pula sebaliknya.

\section{Pengaruh Pemahaman Sumber Daya Manusia terhadap Kualitas Informasi Keuangan}

Berdasarkan hasil pengolahan data pada bagian sebelumnya peneliti menentukan hasil temuan, dimana pemahaman sumber daya manusia $\left(\mathrm{x}_{1}\right)$ memiliki pengaruh yang signifikan positif terhadap kualitas informasi keuangan (y). Untuk menghasilkan informasi keuangan yang bermanfaat, maka dibutuhkan kapasitas sumber daya manusia sebagai salah satu elemen yang sangat penting. Adanya kapasitas sumber daya manusia yang berkualitas, maka akan mempermudah dalam pelaksanaan fungsi akuntansi. Kegagalan sumber daya manusia dalam memahami dan menerapkan logika akuntansi akan berdampak pada kekeliruan laporan keuangan yang dibuat dan ketidaksesuaian informasi keuangan dengan standar yang ditetapkan. Sehingga semakin tinggi tingkat intelektual pemahaman akuntansi, maka semakin cerdas dalam penyusunan laporan keuangan. Sehingga dapat disimpulkan bahwa terdapat pengaruh antara pemahaman sumber daya manusia $\left(\mathrm{x}_{1}\right)$ terhadap kualitas informasi keuangan (y).

Hasil penelitian ini sejalan dengan penelitian yang dilakukan tantriani sukmaningrum (2012) yang menyatakan bahwa sumber daya manusia berpengaruh positif terhadap kualitas informasi laporan keuangan. Sesuai juga dengan penelitian yang dilakukan Kiranayanti dan Erawati (2016) yang menyatakan bahwa sumber daya manusia berpengaruh positif terhadap kualitas laporan keuangan.

\section{Pengaruh Implementasi Standar Akuntansi Pemerintah terhadap Kualitas Informasi Keuangan}

Implementasi standar akuntansi pemerintahan $\left(\mathrm{x}_{2}\right)$ memiliki pengaruh yang signifikan positif terhadap kualitas informasi keuangan (y). Implementasi standar akuntansi pemerintah disusun dalam rangka meningkatkan transparansi dan akuntabilitas dalam pengelolaan keuangan melalui informasi keuangan yang berkualitas. Implementasi perencanaan, pengelolaan anggaran dan penyusunan laporan menggunakan standar akuntansi pemerintah yang baik akan meningkatkan kualitas informasi keuangan. Implementasi standar akuntansi pemerintah akan berdampak pada peningkatan kualitas informasi keuangan. Standar akuntansi pemerintah adalah prinsip-prinsip akuntansi yang diterapkan dalam menyusun dan menyajikan laporan keuangan, sehingga standar akuntansi pemerintah merupakan persyaratan yang mempunyai kekuatan hukum dalam upaya meningkatkan kualitas laporan keuangan pemerintah. Penerapan standar akuntansi pemerintah akan mengarahkan sistem akuntansi dan manajemen 
keuangan pemerintah yang lebih baik sehingga laporan keuangan yang dihasilkan mempunyai informasi yang lebih baik. Sehingga dapat disimpulkan bahwa terdapat pengaruh antara implementasi standar akuntansi pemerintahan $\left(\mathrm{x}_{2}\right)$ terhadap kualitasninformasi keuangan $(\mathrm{y})$.

Hasil penelitian ini sejalan dengan pnelitian yang dilakukan Putra dan amar (2013) yang menyatakan bahwa penerapan standar akuntansi keuangan pemerintah berpengaruh positif terhadap kualitas laporan keuangan. Sesuai juga dengan penelitian yang dilakukan oleh Lestari (2013) yang menyatakan bahwa standar akuntansi pemerintah berpengaruh positif terhadap kualitas laporan keuangan.

\section{Simpulan, keterbatasan dan implikasi hasil penelitian}

Hasil pengujian hipotesis dengan menggunakan analisis regresi linier berganda dengan 2 variabel independen yaitu pemahaman sumber daya manusia dan implementasi standar akuntansi pemerintah dan satu variabel dependen yaitu kualitas informasi keuangan menunjukkan bahwa pemahaman sumber daya manusia berpengaruh signifikan positif terhadap kualitas informasi keuangan. Kesimpulan ini mengindikasikan bahwa pemahaman sumber daya manusia dan upaya peningkatannya berperan dalam menghasilkan informasi keuangan yang relevan, andal, dan dapat dibandingkan dan dapat dipahami.

Implementasi standar akuntansi pemerintah berpengaruh signifikan positif terhadap kualitas informasi keuangan. Kesimpulan ini menunjukkan semakin baik implementasi standar akuntansi pemerintah di kementerian sosial ri, maka semakin baik juga kualitas informasi keuangan yang dihasilkan. Keterbatasan penelitian ini hanya dilakukan di kementerian sosial ri, tidak membandingkan dengan kementerian lain sehingga hasil penelitian belum bisa digeneralisasi untuk seluruh kementerian/ lembaga. Penelitian ini juga menggunakan metode kuesioner sehingga kesimpulan yang dikemukakan berdasarkan pada data yang terkumpul melalui penggunaan instrumen tertulis. Pada penelitian yang akan datang terdapat hal yang perlu diperhatikan yaitu kementerian sosial ri melakukan pelatihan kepada perencana keuangan, pengelola keuangan, dan penyusun laporan keuangan sehingga dapat meningkatkan pemahaman sumber daya manusia dalam kualitas penyajian informasi keuangan dan untuk penelitian selanjutnya sebaiknya tidak hanya terbatas disatu kementerian saja, sehingga hasil penelitian diharapkan dapat memberi kontribusi pada kementerian/ lembaga lain.

\section{Daftar Referensi}

Arikunto, Suharsimi (2005), Manajemen Penelitian, PT Rineka Cipta, Jakarta

Irwana, Toni (2010), Pengaruh Efektivitas Penerapan Standar Akuntansi Pemerintah Terhaap Kualitas Laporan Keuangan. Jurnal Magister Auntansi Universitas Pendidikan Indonesia, Bandung

Kiranayanti, I. A. E., \& Erawati, N. M. A. (2016). Pengaruh Sumber Daya Manusia, Sistem Pengendalian Intern, Pemahaman Basis Akrual Terhadap Kualitas Laporan Keuangan Daerah. E-Jurnal Akuntansi, 1290-1318.

Lestari, Anita Mega (2013), Pengaruh Sumber Daya Manusia, Sistem Pengendalian Intern dan Standar Pemerintah terhadap Kualitas Laporan Keuangan Studi Empiris pada Kementerian Pendidikan Nasiona. Jurnal Magister Akuntansi Pasca sarjana Universitas Diponegoro Semarang

Maksyur, Valenra,Noprial (2015), Pengaruh Kualitas Sumber Daya Manusia, Komitmen Organisasi, Sistem Pengendalian Intern, dan Pemanfaatan Teknologi Informasi Terhadap Kualitas Laporan Keuangan. Jurnal Akuntansi Universitas Padjajaran Bandung 
Nugraheni, P., Subaweh, I. (2011). Pengaruh Penerapan Standar Akuntansi Pemerintahan Terhadap Kualitas Laporan Keuangan. Jurnal Ilmiah Ekonomi Bisnis, 13(1).

Putra, Bayu Dharma, Syamsul Amar (2013), Pengaruh Kompetensi Sumber Daya Manusia, Penerapan Sistem Pengendalian Intern Pemerintah dan Penerapan Standar Akuntansi Pemerintah Terhadap Kualitas Laporan Keuangan Pemerintah Kota Padang. Jurnal Magister Akuntansi Universitas Komputer Indonesia Bandung Ridwan (2006), Metode dan Teknik Menyusun Tesis, Alfabeta, Bandung

Sugiyono (2008), Metode Penelitian Kuantitatif, Kualitatif dan $R$ dan D, Alfabeta, Bandung Sukmaningrum, Tantriani, (2012), Analisis Faktor-Faktor yang Mempengaruhi
Kualitas Informasi Laporan Keuangan Pemerintah Daerah (Stusdi Empiris pada Pemerintah Kabupaten dan Kota Semarang. Jurnal Magister Akuntansi Universitas Diponegoro, Semarang

Suwita, Monica Khairunissa. (2015). Pengaruh Penerapan Standar Akuntansi Pemerintahan Terhadap Kualitas Laporan Keuangan Pemerintah Daerah (Studi Kasus pada Dinas Keuangan Daerah Kabupaten Indramayu) (Doctoral dissertation, Universitas Widyatama).

Yudianta, Erawati, Gede Agus, and Ni Made Adi Erawati. (2012). Pengaruh Sumber Daya Manusia Teknologi Informasi dan Pengendalian Intern terhadap Kualitas Laporan Keuangan. E-Jurnal Akuntansi Universitas Udayana. 